\title{
Uptake of relaxin in the uterus and cervix of rats in vivo: influence of ovarian steroids and tolerance
}

\author{
S. J. Downing* and M. Hollingsworth \\ Smooth Muscle Research Group, Department of Physiological Sciences, University of Manchester, \\ Oxford Road, Manchester M13 9PT, UK
}

\begin{abstract}
The influence of oestradiol benzoate and progesterone treatment and of tolerance to relaxin on the uptake of ${ }^{125}$ I-labelled porcine relaxin by reproductive tissues was investigated in anaesthetized female rats. In ovary-intact rats, ${ }^{125}$ I-labelled relaxin uptake increased with time in reproductive tissues and in tissues concerned with metabolism and excretion. Administration of $50 \mu \mathrm{g}$ unlabelled porcine relaxin before injection of ${ }^{125}$ I-labelled relaxin significantly reduced uptake of ${ }^{125}$ I-labelled relaxin into the uterus and cervix, but had no effect on uptake of ${ }^{125}$ I-labelled relaxin into other tissues, indicating that specific uptake of relaxin was occurring in the uterus and cervix. In ovariectomized rats, treatment with oestradiol benzoate or oestradiol benzoate plus progesterone for 1 day did not significantly increase uterine or cervical ${ }^{125}$ I-labelled relaxin uptake compared with corn oil-treated rats, but induced a significant increase in uterine uptake of ${ }^{125}$ I-labelled relaxin after treatment for 2 days. Induction of tolerance to relaxin by i.v. infusion of a high dose of relaxin significantly reduced uterine and cervical uptake of ${ }^{125} \mathrm{I}$-labelled relaxin at $3 \mathrm{~h}$ after termination of infusion compared with saline-infused rats. By $12 \mathrm{~h}$ after termination of infusion, ${ }^{125} \mathrm{I}$-labelled relaxin uptake in the uterus and cervix was similar in saline-infused rats and in rats given an infusion of relaxin. Infusion of glibenclamide $\left(20 \mathrm{mg} \mathrm{kg}^{-1}\right)$ did not influence uterine or cervical uptake of ${ }^{125}$ I-labelled relaxin; however, treatment with phentolamine ( $10 \mathrm{mg} \mathrm{kg}^{-1}$ ) significantly reduced ${ }^{125}$ I-labelled relaxin uptake in uterus, bladder and jejunum. This study demonstrates that steroid hormone treatment and tolerance modulate relaxin uptake in reproductive tissues.
\end{abstract}

\section{Introduction}

Relaxin is physiologically important during pregnancy in rats for inhibition of uterine contractions, softening of the cervix and a high incidence of live births (Downing and Sherwood, $1985 \mathrm{a}-\mathrm{c}$ ). Uterine sensitivity to relaxin as an inhibitor of spontaneous uterine contractions in nonpregnant rats in vivo is enhanced by oestradiol benzoate and progesterone treatment (Downing and Hollingsworth, 1992a,b). Treatment with a physiological dose of oestradiol benzoate $\left(0.4 \mu \mathrm{g} \mathrm{kg}^{-1}\right.$ day $\left.^{-1}\right)$ for 2 days produced a twofold increase and treatment with oestradiol benzoate plus progesterone produced an eightfold increase in uterine sensitivity to relaxin. Oestrogen pretreatment has also been shown to be necessary for relaxin to induce softening of the cervix and maximum effect of relaxin occurs after pretreatment with oestrogen plus progesterone (Kroc $e t$ al., 1959; Cullen and Harkness, 1960; Downing and Sherwood, $1985 \mathrm{c}, 1986)$. Although there is little information concerning hormonal modulation of specific binding sites for relaxin it has been suggested that oestrogen increases the concentration of binding sites for relaxin in both the uterus and cervix (Mercado-

*Current address and for correspondence: Clore Laboratory for Life Sciences, The University of Buckingham, Hunter Street, Buckingham MK18 IEG, UK. Received 18 October 1992.
Simmen et al., 1982). Osheroff et al. (1992) showed that relaxin binding in the rat uterus was decreased by $53 \%$ following ovariectomy, but was restored to $90 \%$ of normal values following oestrogen treatment. The influence of progesterone on relaxin binding has not previously been investigated.

Tolerance to relaxin as an inhibitor of spontaneous uterine contractions develops during prolonged administration (Wiqvist, 1959; Downing and Hollingsworth, 1992a). Infusion of $20 \mu \mathrm{g}$ relaxin $\mathrm{kg}^{-1} \mathrm{~h}^{-1}$ i.v. for $40 \mathrm{~h}$ produced an eightfold reduction in uterine sensitivity to relaxin (Downing and Hollingsworth, 1992a). By $24 \mathrm{~h}$ after termination of infusion, only partial recovery of uterine sensitivity to relaxin had occurred. Treatment with oestradiol benzoate or oestradiol benzoate plus progesterone did not influence the extent of tolerance development, but in rats treated with oestradiol benzoate plus progesterone, recovery of uterine sensitivity to relaxin after cessation of relaxin infusion was more rapid. Prolonged intravenous infusion of relaxin at a higher rate $\left(50 \mu \mathrm{g} \mathrm{kg}^{-1} \mathrm{~h}^{-1}\right)$ for $40 \mathrm{~h}$ produced a 130 -fold decrease in uterine sensitivity to relaxin. The mechanism of development of tolerance to relaxin is not known, but may be due to phosphorylation of binding sites, uncoupling of binding sites from second messenger systems or internalization and degradation of binding sites, as observed for other drugs and hormones (Levitzki, 1986; Lefkowitz et al., 1990). 
The mechanism by which relaxin inhibits uterine contractions is not fully known. Relaxin induces a moderate increase in myometrial concentrations of cAMP in the presence of phosphodiesterase inhibitors in vitro (Cheah and Sherwood, 1980; Sanborn et al., 1980; Hsu et al., 1985). However, relaxin induces only a very small increase in uterine cAMP concentrations in vivo (Downing et al., 1992). Relaxin is antagonized in vivo by glibenclamide, which blocks ATP-sensitive potassium channels (Downing and Hollingsworth, 1991), but such antagonism was not observed in vitro (Hughes et al., 1992). Phentolamine, which blocks both $\alpha$-adrenoceptors and ATP-sensitive potassium channels (Plant and Henquin, 1990), also delays the onset of inhibition of uterine contractions in vivo by relaxin (Porter et al., 1979).

The aim of this study, therefore, was to determine whether specific uptake of ${ }^{125}$ I-labelled porcine relaxin, as an indicator of relaxin binding sites, occurs in the reproductive tract in anaesthetized rats and is modulated by pretreatment with oestradiol benzoate and progesterone, by induction of tolerance to relaxin or by treatment with glibenclamide or phentolamine.

\section{Materials and Methods}

\section{Experiment $A$ : determination of biological activity of Bolton-Hunter-labelled relaxin}

Porcine relaxin was modified by attachment of Bolton-Hunter reagent (3-p-hydroxyphenyl propionic acid $N$-hydroxysuccinamide ester) (Sigma Chemical Co., Poole, Dorset) by the method of Cheah and Sherwood (1980). Briefly, $5 \mathrm{mg}$ porcine relaxin was stirred with $1.25 \mathrm{mg}$ Bolton-Hunter reagent for $24 \mathrm{~h}$ at $4^{\circ} \mathrm{C}$ in sodium borate buffer $\left(0.1 \mathrm{~mol} \mathrm{l}^{-1}, \mathrm{pH} \mathrm{8.5)}\right.$, and then dialysed extensively against sodium hydrogen orthophosphate $\left(0.001 \mathrm{~mol} \mathrm{l}^{-1}\right)$ and sodium chloride $\left(0.01 \mathrm{~mol} \mathrm{l}^{-1}, \mathrm{pH} \mathrm{11.0)}\right.$ for 4 days to remove small unincorporated molecules. The degree of incorporation of the (3-p-hydroxyphenyl) propionate group into relaxin, estimated by the method of Bencze and Schmid (1957), was approximately $2 \mathrm{~mol}$ (3-p-hydroxyphenyl) propionate into $1 \mathrm{~mol}$ hormone. The protein concentration of Bolton-Hunter-labelled porcine relaxin was determined by the method of Lowry et al. (1951). Tube gel electrophoresis was performed on relaxin and modified relaxin by the method of Davis (1964), using 7.5\% acrylamide, $\mathrm{pH} 4.3$. Relaxin, $50 \mu \mathrm{g}$, or modified relaxin was layered onto the gel in $250 \mu \mathrm{l} 5 \%$ sucrose. Gels were run at $6 \mathrm{~mA}$ per gel for $45 \mathrm{~min}$, fixed and stained in $1 \%$ amido black in $7 \%$ acetic acid, and destained in $7 \%$ acetic acid.

Female rats, 200-250 g, purchased from Charles River (Margate) were anaesthetized with tribromoethanol $(240 \mathrm{mg}$ $\mathrm{kg}^{-1}$, i.p.) and bilaterally ovariectomized. A small latex balloon was placed in one uterine horn and the right jugular vein was cannulated (PP50 tubing, internal diameter $0.58 \mathrm{~mm}$, outside diameter $0.96 \mathrm{~mm}$; Portex Ltd, Hythe). All rats were given $5 \mathrm{mg}$ morphine sulfate $\mathrm{kg}^{-1}$ for post-operative analgesia. Twentyfour hours after surgery, continuous recording of pressure cycles produced by uterine contractions commenced, using Elcomatic EM750 or Statham P23Db pressure transducers and Grass preamplifiers and polygraphs (Grass Co., Quincy, MA). Uterine contractions were defined as a rise and fall of at least
$5 \mathrm{~mm} \mathrm{Hg}$. Contractions were quantified as the integral of the area under the pressure curve produced by contractions using Grass 7P10B integrators (Downing and Hollingsworth, 1992a). Rats were given three or four bolus doses of pig relaxin $(2,5$, $\left.20 \mu \mathrm{g} \mathrm{kg}^{-1}, n=8 \mathrm{rats}\right)$ or Bolton-Hunter-labelled pig relaxin $\left(2,5,20,50 \mu \mathrm{g} \mathrm{kg}^{-1}, n=8\right.$ rats $)$ i.v. in $1 \mathrm{ml}$ saline $\mathrm{kg}^{-1}$. Three hours elapsed between each bolus dose to allow the relaxin to clear. The uterine response to each bolus dose was recorded for $60 \mathrm{~min}$ and expressed as percentage inhibition of the integral of uterine contractions recorded for the $60 \mathrm{~min}$ immediately before each bolus dose. Dose-response curves were constructed for each animal using a logarithmic transformation. $\log \mathrm{ID}_{50}$ values ( $\log$ of dose producing $50 \%$ inhibition of integral of uterine contractions) were estimated by probit analysis using a computer program (Tallarida and Murray, 1987).

\section{Experiment $B$ : time course of relaxin uptake}

Porcine relaxin and porcine insulin were radioiodinated by the method of Cheah and Sherwood (1980) using ${ }^{125}$ I-BoltonHunter reagent (New England Nuclear, Dupont de Nemours, Gmbh., Dreich). Briefly, $5 \mu \mathrm{g}$ porcine relaxin in sodium borate buffer $\left(0.2 \mathrm{~mol} \mathrm{l}^{-1}, \mathrm{pH} 8.5\right)$ was added to $1 \mathrm{mCi}{ }^{125}$ I-labelled Bolton-Hunter reagent and stirred for $1 \mathrm{~h}$ over ice, and then for $3 \mathrm{~h}$ at $4^{\circ} \mathrm{C}$. The ${ }^{125}$ I-labelled relaxin was separated from unreacted ${ }^{125} \mathrm{I}$-Bolton-Hunter reagent and hydrolysed reagent by gel filtration using a $1.4 \mathrm{~cm} \times 25 \mathrm{~cm}$ Sephadex G25 (coarse) column (previously equilibrated with phosphate buffer $10.5 \mathrm{~mol}$ $\left.\mathrm{I}^{-1}, \mathrm{pH} 8.5\right)$ containing $2.5 \%$ gelatin then rinsed with $30-40 \mathrm{ml}$ phosphate buffer, $0.5 \mathrm{~mol}^{-1}$. Fractions $(1.5 \mathrm{ml})$ were collected into tubes containing $0.5 \mathrm{ml}$ phosphate buffer $\left(0.5 \mathrm{~mol} \mathrm{^{-1 }}\right.$, $\mathrm{pH} 8.5$ ) $0.25 \%$ gelatin and the radioactivity in $2 \mu \mathrm{l}$ of each fraction determined. Radiolabelling of insulin was carried out in a similar way. Mean specific activity of ${ }^{125} \mathrm{I}$-labelled relaxin was

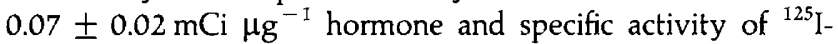
insulin was $0.06 \mathrm{mCi} \mu \mathrm{g}^{-1}$ hormone as estimated by the relative quantities of radioactivity contained in the hormone-bound ${ }^{125} \mathrm{I}$ and unbound ${ }^{125} \mathrm{I}$ peaks eluted from the G-25 Sephadex column.

Female rats were anaesthetized with tribromoethanol $(240 \mathrm{mg}$ $\mathrm{kg}^{-1}$, i.p.) and the right jugular vein and carotid artery cannulated (PP50 polyethylene tubing). ${ }^{125} \mathrm{I}$-labelled porcine relaxin $(5 \mu \mathrm{Ci})$ was given via the jugular cannula in $0.1-0.3 \mathrm{ml}$ phosphate buffer $\left(0.1 \mathrm{~mol} \mathrm{l}^{-1}, \mathrm{pH} 8.5\right)$ and flushed into the animal with $0.5 \mathrm{ml}$ saline $(0.9 \% \mathrm{w} / \mathrm{v} \mathrm{NaCl})$. When the duration of the experiment was greater than $20 \mathrm{~min}$, the dose of $5 \mu \mathrm{Ci}$ ${ }^{125} \mathrm{I}$-labelled relaxin was given as three separate doses of $1.7 \mu \mathrm{Ci}, 20$ or $40 \mathrm{~min}$ apart. Anaesthesia was maintained throughout with tribromoethanol given i.v. via the jugular cannula. At $20 \mathrm{~min}$ ( $n=5 \mathrm{rats}$ ), $60 \mathrm{~min}$ ( $n=5$ rats) or $120 \mathrm{~min}$ ( $n=5$ rats) after the first injection of ${ }^{125}$ I-labelled relaxin, blood $(1 \mathrm{ml})$ was taken via the carotid cannula and placed in a vial for determination of radioactivity. The animals were immediately killed by an overdose of tribromoethanol. Reproductive (ovaries, uterus, cervix and vagina) and other tissues (bladder, jejunum, ileum, pancreas, liver, spleen, kidney, lung, diaphragm, ventricle of heart) were rapidly dissected out and samples of up to $500 \mathrm{mg}$ were placed in pre-weighed vials. The vials were reweighed to determine wet weight of the tissues. The radioactivity in the blood and tissue samples was determined and the radioactivity 
(c.p.m.) obtained per $100 \mathrm{mg}$ of tissue was divided by the radioactivity (c.p.m.) obtained per $100 \mu \mathrm{l}$ of blood. A ratio of counts significantly greater than 1.0 indicates uptake of ${ }^{125} \mathrm{I}$-labelled relaxin.

The following three experiments were performed to determine the specificity of uptake of ${ }^{125}$ I-labelled relaxin. One group of rats was given $50 \mu \mathrm{g}$ unlabelled porcine relaxin i.v. just before the first injection of ${ }^{125}$ I-labelled relaxin $(n=5)$ and blood and tissue samples were taken $60 \mathrm{~min}$ after the first injection of ${ }^{125} \mathrm{I}$ labelled relaxin $(60 \mathrm{~min}$ was selected to ensure that sufficient unlabelled relaxin remained in the circulation to compete with ${ }^{125}$ I-labelled relaxin). A second group of rats was given $5 \mu \mathrm{C}$ unconjugated ${ }^{125} \mathrm{I}$-Bolton-Hunter reagent i.v. and blood and tissue samples were taken at $20 \min (n=5), 60 \min (n=5)$ or $120 \min (n=5)$ after the first injection of ${ }^{125}$ I-Bolton-Hunter reagent. Some of the rats were given $50 \mu \mathrm{g}$ unlabelled relaxin i.v. just before the first injection of ${ }^{125} \mathrm{I}$-Bolton-Hunter reagent and blood and tissue samples were taken $60 \mathrm{~min}$ after the first injection of ${ }^{125} \mathrm{I}$-Bolton-Hunter reagent $(n=5)$. A third group of rats was given $5 \mu \mathrm{Ci}^{125}$ I-labelled porcine insulin $(n=5)$ or $50 \mu \mathrm{g}$ unlabelled relaxin just before the first injection of ${ }^{125} \mathrm{I}$ labelled insulin $(n=5)$ and blood and tissue samples were taken 60 min after the first injection of ${ }^{125}$ I-labelled insulin.

\section{Experiment $C$ : influence of oestradiol benzoate and progesterone on uptake of relaxin}

Rats were anaesthetized with tribromoethanol $\left(240 \mathrm{mg} \mathrm{kg}^{-1}\right.$, i.p.) and subjected to bilateral ovariectomy via flank laparotomy. Rats were given $5 \mathrm{mg}$ morphine sulfate $\mathrm{kg}^{-1}$ s.c. postoperatively for analgesia. The animals were then treated with one of the following: corn oil $\left(1 \mathrm{ml} \mathrm{kg}^{-1}\right)$ s.c. daily for 1 ( $n=5$ rats) or 2 days ( $n=5$ rats); oestradiol benzoate $\left(0.4 \mu \mathrm{g} \mathrm{kg}^{-1}\right.$ in $1 \mathrm{ml}$ corn oil $\mathrm{kg}^{-1}$ ) s.c. daily for $I$ ( $n=5$ rats) or 2 days ( $n=5$ rats); oestradiol benzoate $\left(40 \mu \mathrm{g} \mathrm{kg}^{-1}\right.$ in $1 \mathrm{ml}$ corn oil kg $\left.{ }^{-1}\right)$ s.c. daily for 2 days ( $n=9$ rats); oestradiol benzoate $\left(0.4 \mu \mathrm{g} \mathrm{kg}^{-1}\right)$ plus progesterone $\left(4 \mathrm{mg} \mathrm{kg}^{-1}\right)$ s.c. in $1 \mathrm{ml}$ corn oil kg-1 daily for 1 ( $n=5$ rats) or 2 days ( $n=5$ rats).

Uptake by reproductive and other tissues of $3 \times 1.7 \mu \mathrm{Ci}$ ${ }^{125}$ I-labelled relaxin given i.v. under tribromoethanol anaesthesia was then determined as described for Expt B for 120 min. Rats treated with $40 \mu \mathrm{g}$ oestradiol benzoate $\mathrm{kg}^{-1}$ received either $3 \times 1.7 \mu \mathrm{Ci}{ }^{125}$ I-labelled relaxin i.v. alone $(n=5)$ or $50 \mu \mathrm{g}$ unlabelled relaxin just before the first injection of ${ }^{125}$ I-labelled relaxin $(n=4$ rats)

\section{Experiment $D$ : influence of tolerance on relaxin uptake}

Rats were anaesthetized with tribromoethanol $\left(240 \mathrm{mg} \mathrm{kg}^{-1}\right.$, i.p.) subjected to bilateral ovariectomy and the right jugular vein cannulated; the cannula tubing passed subcutaneously to the back of the neck, where it was exteriorized and protected by a long metal spring which allowed the animals largely unrestricted movement within the cages. The rats were given $5 \mathrm{mg}$ morphine sulfate $\mathrm{kg}^{-1}$ s.c. postoperatively for analgesia. The rats were then given one of the following: saline infusion i.v. at $0.15 \mathrm{ml} \mathrm{h}^{-1}$ for $40 \mathrm{~h}(n=15$ rats); relaxin infusion i.v. at $20 \mu \mathrm{g} \mathrm{kg}^{-1} \mathrm{~h}^{-1}(n=11$ rats $)$ or $50 \mu \mathrm{g} \mathrm{kg}^{-1} \mathrm{~h}^{-1}(n=20$ rats) in $0.15 \mathrm{ml}$ saline $\mathrm{h}^{-1}$ for $40 \mathrm{~h}$. These rates of infusion of relaxin have previously been shown to produce eightfold and 130-fold reductions in uterine sensitivity to relaxin as an inhibitor of spontaneous contractions, respectively (Downing and Hollingsworth, 1992a).

At 3 or $12 \mathrm{~h}$ after termination of infusion, uptake by reproductive and other tissues of ${ }^{125}$ I-labelled relaxin $(3 \times 1.7 \mu \mathrm{Ci}$, i.v.) was then determined over $\mathbf{1 2 0}$ min under tribromoethanol anaesthesia as described for Expt B. Three hours after termination of infusion was selected as the earliest time to test uptake of ${ }^{125}$-labelled relaxin to allow relaxin in the infusate to clear. Studies have shown that relaxin has a half-life of approximately $20 \mathrm{~min}$ in plasma (Sherwood et al, 1984). Four saline-infused rats and nine rats given an infusion of relaxin at $50 \mu \mathrm{g} \mathrm{kg}^{-1} \mathrm{~h}^{-1}$ received $50 \mu \mathrm{g}$ or $100 \mu \mathrm{g}$ unlabelled relaxin i.v. just before the first injection of ${ }^{125}$ I-labelled relaxin.

\section{Experiment E: influence of glibenclamide and phentolamine on relaxin uptake}

Rats were anaesthetized with tribromoethanol $\left(240 \mathrm{mg} \mathrm{kg}^{-1}\right.$, i.p.) and subjected to bilateral ovariectomy. The animals were given $5 \mathrm{mg}$ morphine sulfate $\mathrm{kg}^{-1}$ s.c. postoperatively for analgesia. Twenty-four hours after surgery, the animals were again anaesthetized with tribromoethanol and the right jugular vein and carotid artery cannulated. Groups of animals were then treated with either an infusion of glibenclamide $\left(20 \mathrm{mg} \mathrm{kg}^{-1}\right.$, $n=5$ rats $)$ or vehicle $\left(0.2 \mathrm{~mol}\right.$ sodium hydroxide $1^{-1}$ in $4 \%$ w/v glucose, $5 \mathrm{ml} \mathrm{kg}^{-1}, n=5$ rats) i.v. over $5 \mathrm{~min}$. This dose of glibenclamide produces more than 19-fold antagonism of relaxin as an inhibitor of spontaneous contractions in vivo (Downing and Hollingsworth, 1991). Other groups were given an injection of phentolamine ( $10 \mathrm{mg} \mathrm{kg}{ }^{-1}, n=5$ rats) or saline ( $1 \mathrm{ml} \mathrm{kg}{ }^{-1}, n=5$ rats) i.v. This dose of phentolamine delays the onset of inhibition of uterine contractions by relaxin (Porter et al., 1979). Fifteen minutes after infusion or injection, the rats were given ${ }^{125}$ I-labelled relaxin $(3 \times 1.7 \mu \mathrm{Ci})$ i.v. and blood and tissue samples were taken at $60 \mathrm{~min}$ after the first injection of ${ }^{125}$ I-labelled relaxin as described for Expt B. The period of $60 \mathrm{~min}$ was selected as it has been found that the effectiveness of glibenclamide as an antagonist of relaxin declines markedly after this time in rats (Downing and Hollingsworth, 1991).

\section{Reagents}

Porcine relaxin was isolated and purified from pregnant sow ovaries by the method of Sherwood and O'Byrne (1974). Relaxin potency was bioassayed in vitro by inhibition of contractions of electrically stimulated uterus from oestrogen pretreated rats $\left(100 \mu \mathrm{g}\right.$ oestradiol benzoate $\mathrm{kg}^{-1}$ s.c.) (Bradshaw et al., 1981), using highly purified porcine relaxin, kindly donated by O.D. Sherwood (University of Illinois, Urbana, IL) as standard. Our relaxin preparation was equipotent with highly purified relaxin. Porcine insulin, oestradiol benzoate, progesterone and phentolamine were obtained from Sigma Chemical Co. (Poole, Dorset). Glibenclamide was supplied by Hoechst Ltd (Hounslow). Tribromoethanol was obtained from Fluka Chemicals (Glossop) and morphine sulfate from Evans Ltd (Dunstable). All other reagents were of Analar grade. 


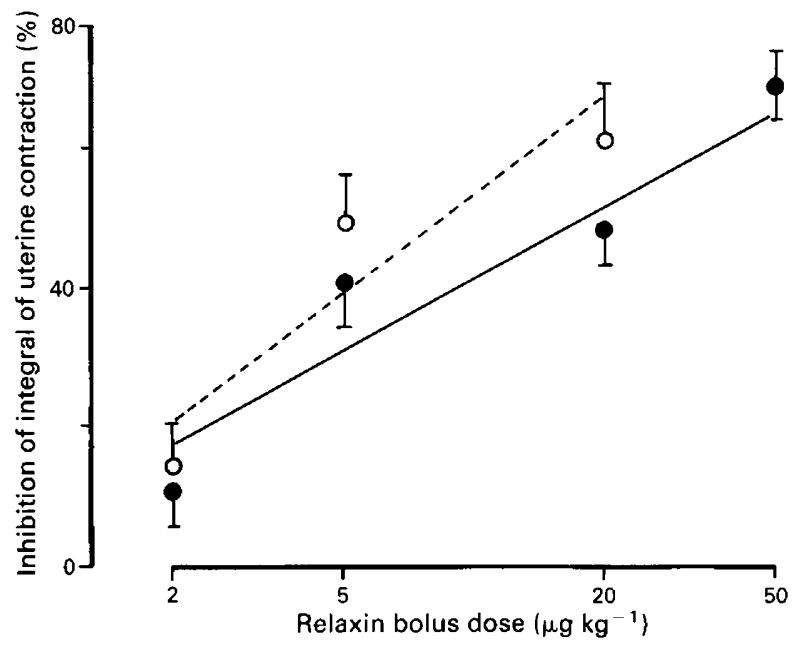

Fig. 1. Dose-response curves for inhibition of uterine contractions by porcine relaxin $(\mathrm{O}$, eight rats) and Bolton-Hunter-labelled porcine relaxin $(\mathcal{O}$, eight rats). Values are means $\pm \mathrm{SEM}$. Ordinate: inhibition of uterine contractions over $60 \mathrm{~min}$ as a $\%$ of integral of $60 \mathrm{~min}$ preceding i.v. bolus dose. Abscissa: dose on a log scale.

\section{Statistical analysis}

Results are presented as means \pm SEM. Values were compared statistically by analysis of variance followed by Student's $t$ test.

\section{Results}

\section{Experiment A: determination of biological activity of Bolton-Hunter-labelled relaxin}

There were no significant differences in $\log \mathrm{ID}_{50}$ values (porcine relaxin, $0.92 \pm 0.12 \mu \mathrm{g} \mathrm{kg}^{-1}$; Bolton-Hunter relaxin, $1.19 \pm 0.14 \mu \mathrm{g} \mathrm{kg}^{-1}$ ) or slopes of the regression lines for the dose-response curves (porcine relaxin, $45.8 \pm 10.9 \% \mu \mathrm{g}^{-1}$ $\mathrm{kg}^{-1}$; Bolton-Hunter relaxin, $34.1 \pm 6.0 \% \mu^{-1} \mathrm{~kg}^{-1}$ ) (Fig. 1). There was, therefore, no significant change in biological activity of relaxin as an inhibitor of uterine contractions owing to attachment of Bolton-Hunter reagent to porcine relaxin. Gel electrophoresis of relaxin and modified relaxin produced protein bands that were clearly separated suggesting that biological activity of modified relaxin was not due to residual unmodified relaxin in the preparation.

\section{Experiment B: time course of uptake of ${ }^{125}$ I-labelled relaxin}

Values of ratios of ${ }^{125}$ I content in tissues compared with ${ }^{125} \mathrm{I}$ content of blood (relative uptake) at various times after injection of ${ }^{125}$ I-labelled relaxin are shown (Table 1 ) and ratios at various times after injection of unconjugated ${ }^{125} \mathrm{I}$-BoltonHunter reagent or ${ }^{125} \mathrm{I}$-labelled insulin, with or without prior injection of $50 \mu \mathrm{g}$ unlabelled relaxin are shown (Table 2). Relative uptake of ${ }^{125}$ I-labelled relaxin in reproductive tissues had a ratio of greater than 1.0 at $20 \mathrm{~min}$ and increased significantly (two- to three-fold) with time. Tissues concerned with metabolism or excretion also showed increased uptake of ${ }^{125}$ I-labelled relaxin with time (bladder, jejunum, pancreas, liver, kidney, lung). Other organs containing muscle (diaphragm, ileum) or spleen showed no consistent uptake of ${ }^{125}$ I-labelled relaxin. Samples of ventricles of the heart showed no consistent uptake of relaxin. Injection of $50 \mu \mathrm{g}$ unlabelled relaxin just before injection of ${ }^{125}$-labelled relaxin resulted in significant reduction in uptake of ${ }^{125}$ I-labelled relaxin in uterus and cervix indicating that the enhanced ${ }^{125} \mathrm{I}$ content of these tissues was due to specific uptake of relaxin (Table 1). ${ }^{125}$ I-labelled relaxin uptake in other tissues was unaffected by prior injection of unlabelled relaxin. In reproductive and nonreproductive tissues, there was no consistent uptake of label after injection of ${ }^{125} \mathrm{I}$ Bolton-Hunter reagent or ${ }^{125}$ I-labelled insulin whether or not this had been preceded by treatment with unlabelled relaxin (Table 2).

\section{Experiment $C$ : influence of oestradiol benzoate and progesterone on uptake of relaxin}

Reproductive tissues. Treatment of ovariectomized rats with $0.4 \mu \mathrm{g}$ oestradiol benzoate $\mathrm{kg}^{-1}$ for 1 or 2 days did not significantly change uterine wet weight (corn oil treatment for 1 day, $315 \pm 32 \mathrm{mg}$; corn oil treatment for 2 days, $289 \pm 15 \mathrm{mg}$; $0.4 \mu \mathrm{g}$ oestradiol benzoate $\mathrm{kg}^{-1}$ for $\mathrm{I}$ day, $278 \pm 18 \mathrm{mg}$; $0.4 \mu \mathrm{g}$ oestradiol benzoate $\mathrm{kg}^{-1}$ for 2 days, $279 \pm 23 \mathrm{mg}$ ). Similarly, cervical wet weight was not altered by treatment for 1 or 2 days with $0.4 \mu \mathrm{g}$ oestradiol benzoate $\mathrm{kg}^{-1}(65 \pm 6 \mathrm{mg}$, $65 \pm 4 \mathrm{mg}$, respectively) or $0.4 \mu \mathrm{g}$ oestradiol benzoate $\mathrm{kg}^{-1}$ plus $4 \mathrm{mg}$ progesterone $\mathrm{kg}^{-1}(93 \pm 5 \mathrm{mg}, 62 \pm 3 \mathrm{mg}$, respectively) compared with corn oil treatment ( $90 \pm 7 \mathrm{mg}$, $73 \pm 5 \mathrm{mg}$, respectively). Uterine uptake of ${ }^{125}$ I-labelled relaxin was significantly increased by treatment with $0.4 \mu \mathrm{g}$ oestradiol benzoate $\mathrm{kg}^{-1}$ for 2 days $(P<0.01$, Fig. $2 \mathrm{a}, \mathrm{b})$ compared with corn oil treatment. Treatment with $0.4 \mu \mathrm{g}$ oestradiol benzoate $\mathrm{kg}^{-1}$ plus $4 \mathrm{mg}$ progesterone $\mathrm{kg}^{-1}$ for 1 or 2 days again did not significantly increase uterine wet weight $(329 \pm 8 \mathrm{mg}$, $305 \pm 15 \mathrm{mg}$, respectively), but significantly increased uterine uptake of ${ }^{125}$ I-labelled relaxin after treatment for 2 days $(P<0.02$ compared with corn oil-treated rats, Fig. 2 a). Treatment with $40 \mu \mathrm{g}$ oestradiol benzoate $\mathrm{kg}^{-1}$ for 2 days produced a significant increase in uterine wet weight $(510 \pm 30 \mathrm{mg}$, $p<0.001)$ and significantly increased uterine uptake of ${ }^{125}{ }_{1-}$ labelled relaxin compared with corn oil-treated rats $(P<0.001)$ and rats treated with the lower dose of oestradiol benzoate with $(P<0.01)$ or without $(P<0.01)$ progesterone for 2 days.

Unlike results observed for the uterus, treatment with $0.4 \mu \mathrm{g}$ oestradiol benzoate $\mathrm{kg}^{-1}$ or $0.4 \mu \mathrm{g}$ oestradiol benzoate $\mathrm{kg}^{-1}$ plus $4 \mathrm{mg}$ progesterone $\mathrm{kg}^{-1}$ for 2 days did not significantly increase cervical uptake of ${ }^{125} \mathrm{I}$-labelled relaxin. Treatment of rats with $40 \mu \mathrm{g}$ oestradiol benzoate $\mathrm{kg}^{-1}$ for 2 days produced significant increases in both cervical wet weight $(122 \pm 7 \mathrm{mg}$, $P<0.001$ ) and ${ }^{125}$ I-labelled relaxin uptake compared with corn oil-treated rats $(P<0.01)$ and rats treated with the lower dose of oestradiol benzoate with $(P<0.02)$ or without $(P<0.05)$ progesterone (Fig. 2b). The marked increase in uptake of ${ }^{125} \mathrm{I}$ labelled relaxin observed in uteri and cervix from rats treated with $40 \mu \mathrm{g}$ oestradiol benzoate $\mathrm{kg}^{-1}$ for 2 days was abolished by prior injection of $50 \mu \mathrm{g}$ unlabelled relaxin $(P<0.001$, Fig. $2 a, b)$. 
Table 1. Ratios of ${ }^{125} \mathrm{I}$ content in tissues compared with ${ }^{125} \mathrm{I}$ content of blood at 20,60 or 120 min after injection of $5 \mu \mathrm{Ci}^{125} \mathrm{I}$-relaxin in intact rats or at $60 \mathrm{~min}$ after injection of $50 \mu \mathrm{g}$ unlabelled relaxin and $5 \mu \mathrm{Ci}^{125} \mathrm{I}$-labelled relaxin

\begin{tabular}{|c|c|c|c|c|}
\hline Treatment & & $5 \mu \mathrm{Ci}^{125}$ I-relaxin & & $\begin{array}{l}50 \mu \mathrm{g} \text { unlabelled relaxin } \\
+5 \mu \mathrm{Ci}{ }^{125} \mathrm{I} \text {-labelled relaxin }\end{array}$ \\
\hline Time for uptake (min) & 20 & 60 & 120 & 60 \\
\hline \multicolumn{5}{|l|}{ Tissues } \\
\hline Ovaries & $0.92 \pm 0.02^{\mathrm{g}}$ & $1.05 \pm 0.08^{\mathrm{d}}$ & $1.33 \pm 0.09^{\mathrm{d}, g}$ & $0.88 \pm 0.04$ \\
\hline Uterus & $1.50 \pm 0.13^{\mathrm{a}}$ & $2.33 \pm 0.33^{\text {a.e.h }}$ & $4.00 \pm 0.20^{\mathrm{h}}$ & $1.06 \pm 0.06^{e}$ \\
\hline Cervix & $1.93 \pm 0.22^{\mathrm{b}}$ & $3.13 \pm 0.48^{\mathrm{b}, \mathrm{f}, \mathrm{i}}$ & $5.85 \pm 0.24^{\mathrm{i}}$ & $1.29 \pm 0.15^{f}$ \\
\hline Vagina & $2.07 \pm 0.46^{c}$ & $4.79 \pm 1.47$ & $5.73 \pm 1.28^{\mathrm{c}}$ & $2.71 \pm 0.74$ \\
\hline Bladder & $1.30 \pm 0.06^{\mathrm{k}}$ & $4.51 \pm 1.40^{k}$ & $4.26 \pm 0.74$ & $3.66 \pm 0.92$ \\
\hline Jejunum & $1.10 \pm 0.10^{\mathrm{m} . \mathrm{p}}$ & $3.69 \pm 0.35^{\mathrm{m}}$ & $4.71 \pm 1.06^{\mathrm{P}}$ & $3.41 \pm 0.37$ \\
\hline Pancreas & $2.29 \pm 0.05^{q . t}$ & $2.70 \pm 0.07^{9}$ & $2.85 \pm 0.11^{t}$ & $2.85 \pm 0.06$ \\
\hline Liver & $2.29 \pm 0.06^{\mathrm{ru}}$ & $2.76 \pm 0.09^{r}$ & $2.81 \pm 0.07^{\mathrm{u}}$ & $2.97 \pm 0.07$ \\
\hline Kidney & $25.15 \pm 0.26$ & $24.54 \pm 2.03^{n}$ & $33.95 \pm 2.92^{n}$ & $29.99 \pm 2.19$ \\
\hline Lung & $1.43 \pm 0.05^{\mathrm{s}}$ & $1.90 \pm 0.12^{\mathrm{s}}$ & $1.99 \pm 0.13$ & $1.78 \pm 0.04$ \\
\hline Diaphragm & $0.43 \pm 0.01$ & $0.46 \pm 0.03$ & $0.44 \pm 0.02$ & $0.44 \pm 0.01$ \\
\hline Heart & $0.55 \pm 0.03$ & $0.51 \pm 0.04$ & $0.45 \pm 0.03$ & $0.45 \pm 0.02$ \\
\hline Ileum & $0.54 \pm 0.02$ & $2.84 \pm 1.36$ & $1.00 \pm 0.38$ & $1.66 \pm 0.90$ \\
\hline Spleen & $0.93 \pm 0.03$ & $1.08 \pm 0.10$ & $1.21 \pm 0.13$ & $1.17 \pm 0.08$ \\
\hline$n$ & 5 & 5 & 5 & 5 \\
\hline
\end{tabular}

Values are means \pm SEM. Values with the same superscripts are significantly different: $\mathrm{a}, \mathrm{b}, \mathrm{c}, \mathrm{k}, P<0.05 ; \mathrm{d}, \mathrm{m}, \mathrm{n}, P<0.02 ; \mathrm{e}, \mathrm{f}, \mathrm{p}, \mathrm{q}, \mathrm{r}, \mathrm{s}, P<0.01 ; \mathrm{g}, \mathrm{p}<0.002 ; \mathrm{h}, \mathrm{i}$, $t, u, P<0.001$ (analysis of variance followed by Student's $t$ test).

Table 2. Ratios of ${ }^{125} \mathrm{I}$ content in tissues compared with ${ }^{125} \mathrm{I}$ content of blood at 20,60 or 120 min after injection of $5 \mu \mathrm{Ci}^{125} \mathrm{I}$-labelled Bolton-Hunter reagent or ${ }^{125}$ I-labelled insulin in intact rats

\begin{tabular}{|c|c|c|c|c|c|c|}
\hline \multirow{2}{*}{$\begin{array}{l}\text { Treatment } \\
\text { Time for uptake (min) }\end{array}$} & \multicolumn{3}{|c|}{$5 \mu \mathrm{Ci}{ }^{125}$ I-Boiton-Hunter reagent } & \multirow{2}{*}{$\begin{array}{c}50 \mu \mathrm{g} \text { unlabelled } \\
\text { relaxin }+5 \mu \mathrm{Ci} \\
{ }^{125} \text { I-Bolton-Hunter reagent } \\
60\end{array}$} & \multirow{2}{*}{$\begin{array}{c}5 \mu \mathrm{Ci} \\
{ }^{125} \mathrm{I} \text {-labelled } \\
\text { insulin } \\
60\end{array}$} & \multirow{2}{*}{$\begin{array}{c}50 \mu g \text { unlabelled } \\
\text { relaxin }+5 \mu \mathrm{Ci} \\
{ }^{125} \text { I-labelled insulin } \\
60\end{array}$} \\
\hline & 20 & 60 & 120 & & & \\
\hline \multicolumn{7}{|l|}{ Tissues } \\
\hline Ovaries & $1.12 \pm 0.24$ & $0.54 \pm 0.04$ & $0.50 \pm 0.01$ & $0.70 \pm 0.05$ & $0.85 \pm 0.18$ & $0.66 \pm 0.03$ \\
\hline Uterus & $0.77 \pm 0.09$ & $0.55 \pm 0.06$ & $0.75 \pm 0.04$ & $0.68 \pm 0.02$ & $0.81 \pm 0.06$ & $0.91 \pm 0.07$ \\
\hline Cervix & $1.58 \pm 0.45$ & $0.58 \pm 0.04$ & $0.65 \pm 0.04$ & $0.89 \pm 0.16$ & $0.83 \pm 0.05$ & $0.92 \pm 0.10$ \\
\hline Vagina & $2.36 \pm 0.31$ & $1.24 \pm 0.46$ & $0.74 \pm 0.05$ & $4.21 \pm 1.19$ & $1.14 \pm 0.12$ & $1.08 \pm 0.14$ \\
\hline Bladder & $15.4 \pm 7.74$ & $6.92 \pm 0.85$ & $13.85 \pm 2.13$ & $11.14 \pm 2.25$ & $5.08 \pm 1.09$ & $5.24 \pm 0.96$ \\
\hline Jejunum & $2.02 \pm 0.43$ & $2.49 \pm 0.57$ & $1.12 \pm 0.14$ & $1.17 \pm 0.22$ & $4.96 \pm 2.13$ & $3.74 \pm 0.42$ \\
\hline Pancreas & $2.91 \pm 1.16$ & $0.79 \pm 0.23$ & $0.55 \pm 0.02$ & $0.71 \pm 0.13$ & $1.12 \pm 0.09$ & $1.07 \pm 0.12$ \\
\hline Liver & $2.87 \pm 1.18$ & $0.66 \pm 0.21$ & $0.48 \pm 0.02$ & $0.61 \pm 0.11$ & $1.14 \pm 0.08$ & $1.03 \pm 0.11$ \\
\hline Kidney & $3.61 \pm 0.87$ & $1.95 \pm 0.65$ & $1.11 \pm 0.09$ & $2.45 \pm 0.77$ & $7.20 \pm 0.81$ & $8.82 \pm 1.02$ \\
\hline Lung & $1.08 \pm 0.29$ & $0.65 \pm 0.03$ & $0.68 \pm 0.03$ & $1.23 \pm 0.42$ & $0.88 \pm 0.13$ & $1.02 \pm 0.04$ \\
\hline Diaphragm & $0.78 \pm 0.29$ & $0.41 \pm 0.05$ & $0.39 \pm 0.01$ & $0.41 \pm 0.03$ & $0.49 \pm 0.05$ & $0.43 \pm 0.03$ \\
\hline Heart & $0.49 \pm 0.12$ & $0.34 \pm 0.02$ & $0.39 \pm 0.03$ & $0.38 \pm 0.02$ & $0.50 \pm 0.01$ & $0.48 \pm 0.04$ \\
\hline Ileum & $0.87 \pm 0.21$ & $1.73 \pm 0.68$ & $3.32 \pm 0.98$ & $1.08 \pm 0.58$ & $1.00 \pm 0.18$ & $0.76 \pm 0.06$ \\
\hline Spleen & $1.89 \pm 0.71$ & $0.55 \pm 0.14$ & $0.50 \pm 0.05$ & $0.48 \pm 0.07$ & $0.58 \pm 0.07$ & $0.55 \pm 0.03$ \\
\hline$n$ & 5 & 5 & 5 & 5 & 5 & 5 \\
\hline
\end{tabular}




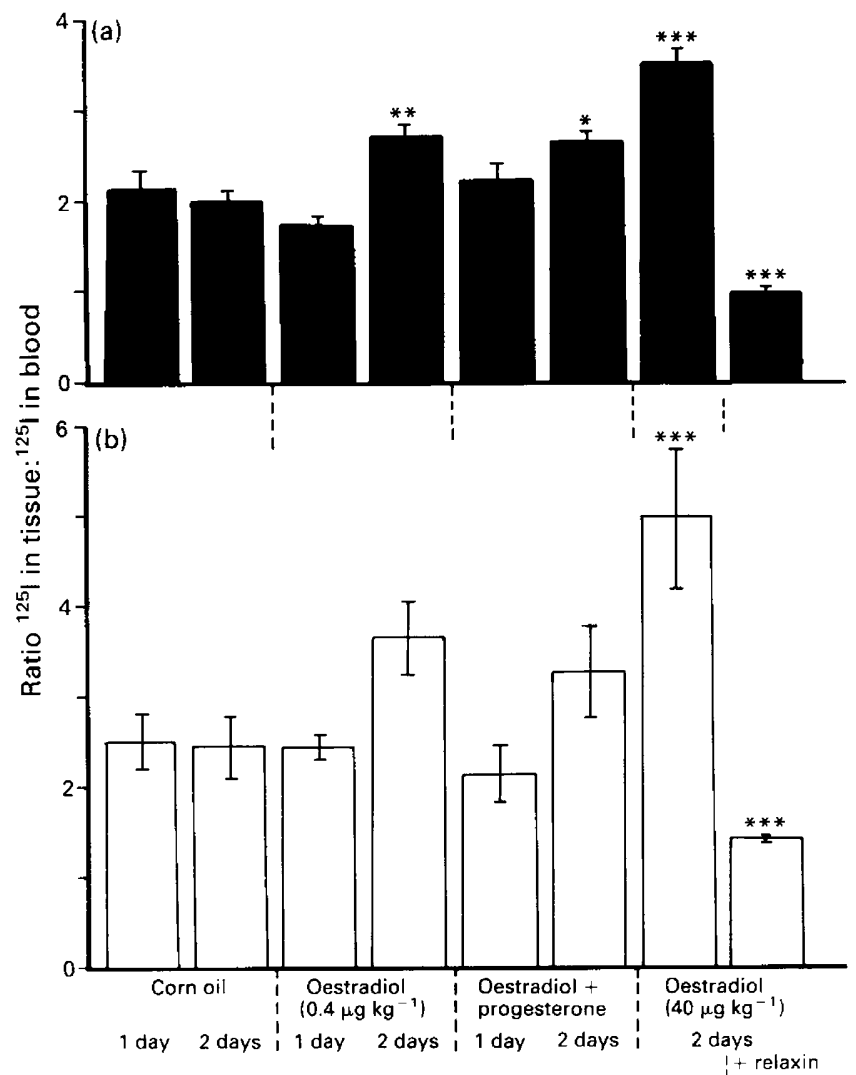

Fig. 2. Ratios of ${ }^{125}$ I content of tissue compared with ${ }^{125}$ I content of blood at $120 \mathrm{~min}$ after injection of $5 \mu \mathrm{Ci}{ }^{125} \mathrm{I}$-labelled relaxin for (a) uterus and (b) cervix in rats treated daily with corn oil only for 1 (five rats) or 2 days (five rats), $0.4 \mu \mathrm{g}$ oestradiol benzoate $\mathrm{kg}^{-\mathrm{I}}$ for $\mathrm{I}$ (five rats) or 2 days (five rats), $0.4 \mu \mathrm{g}$ oestradiol benzoate $\mathrm{kg}^{-1}$ plus $4 \mathrm{mg}$ progesterone $\mathrm{kg}^{-1}$ for 1 (five rats) or 2 days (five rats) or $40 \mu \mathrm{g}$ oestradiol benzoate $\mathrm{kg}^{-1}$ for 2 days (five rats) with administration of $50 \mathrm{\mu g}$ unlabelled relaxin just before injection of ${ }^{12.5} \mathrm{I}$-labelled relaxin (four rats). Histograms show means \pm SEM. Significant differences from corn-oil treated control: ${ }^{*} P<0.02 ;{ }^{* *} P<0.01$; ${ }^{* * *} P<0.001$, except for oestradiol benzoate-treated rats $\left(40 \mu \mathrm{g} \mathrm{kg}^{-1}\right)$ given unlabelled relaxin which are compared with oestradiol benzoatetreated rats which have not received unlabelled relaxin.

Nonreproductive tissues. Values for ratios of ${ }^{125}$ I content in tissues compared with ${ }^{125}$ I content of blood at 120 min were similar in nonreproductive tissues from rats treated with corn oil for 1 or 2 days to those values shown in Table 1 . Treatment with oestradiol benzoate ( 0.4 or $40 \mathrm{~g} \mathrm{~kg}^{-1}$ for 1 or 2 days) or $0.4 \mu \mathrm{g}$ oestradiol benzoate $\mathrm{kg}^{-1}$ plus $4 \mathrm{mg}$ progesterone $\mathrm{kg}^{-1}$ did not affect ${ }^{125}$ I-labelled relaxin uptake in nonreproductive tissues, nor were values significantly reduced by administration of $50 \mu \mathrm{g}$ unlabelled relaxin before injections of ${ }^{125}$ I-labelled relaxin (data not shown).

\section{Experiment $D$ : influence of tolerance on uptake of relaxin}

Reproductive tissues. At $3 \mathrm{~h}$ after termination of infusion relative uptake of ${ }^{125} \mathrm{I}$-labelled relaxin was similar in rats given an i.v. infusion of saline or relaxin at $20 \mu \mathrm{g} \mathrm{kg}^{-1} \mathrm{~h}^{-1}$ for $40 \mathrm{~h}$

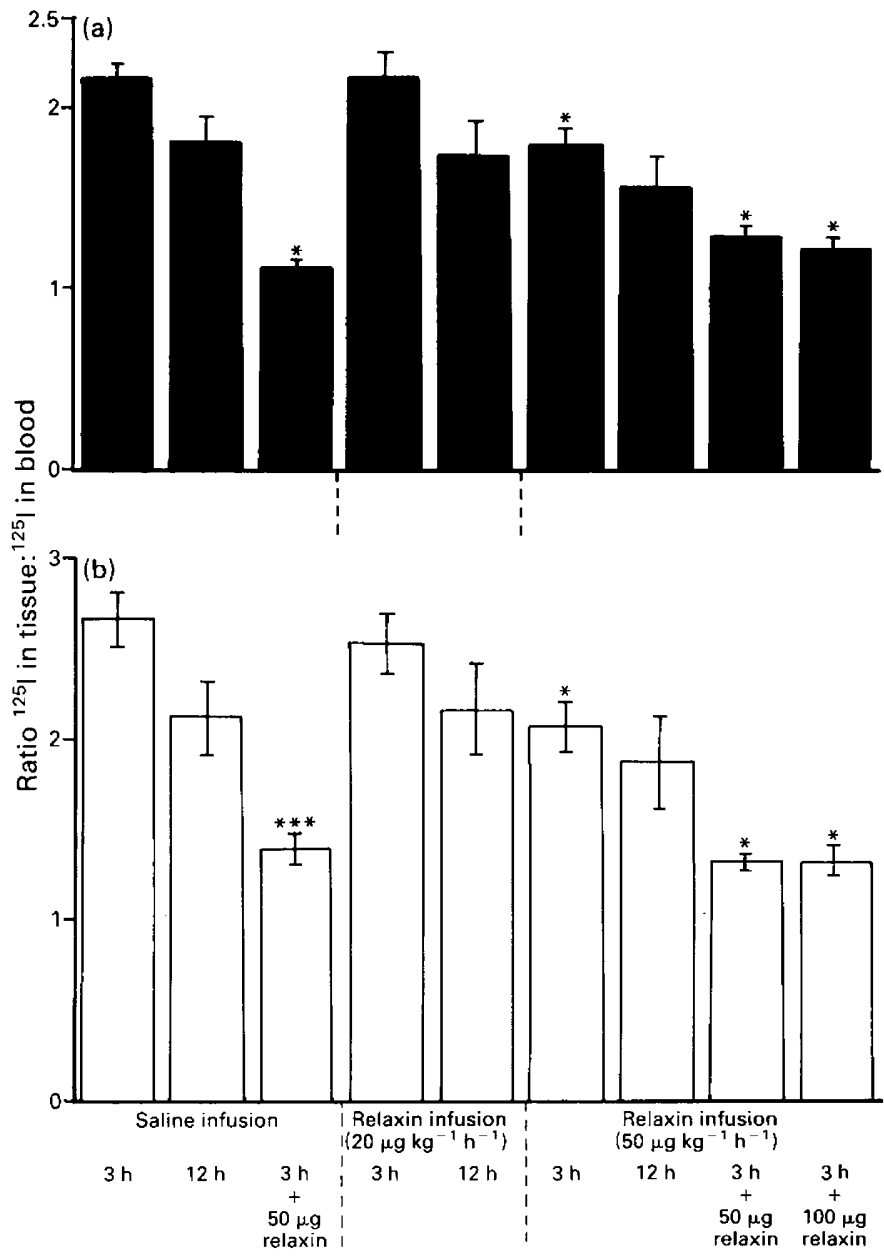

Fig. 3. Ratios of ${ }^{125} \mathrm{I}$ content of tissue compared with ${ }^{125} \mathrm{I}$ content of blood at $120 \mathrm{~min}$ after injection of $5 \mu \mathrm{Ci}{ }^{125} \mathrm{I}$-labelled relaxin for (a) uterus and (b) cervix at $3 \mathrm{~h}$ or $12 \mathrm{~h}$ after termination of infusion in rats given an i.v. infusion of saline at $0.15 \mathrm{ml} \mathrm{h}^{-1}(3 \mathrm{~h}$, five rats; $12 \mathrm{~h}$, six rats; $3 \mathrm{~h}$ with administration of $50 \mu \mathrm{g}$ unlabelled relaxin just before injection of ${ }^{125} \mathrm{I}$-labelled relaxin (four rats), or relaxin at $20 \mu \mathrm{g} \mathrm{kg}^{-1} \mathrm{~h}^{-1}$ ( $3 \mathrm{~h}$, five rats; $12 \mathrm{~h}$, six rats) or $50 \mu \mathrm{g} \mathrm{kg}^{-1} \mathrm{~h}^{-1}$ ( $3 \mathrm{~h}$, five rats; $12 \mathrm{~h}$, six rats; $3 \mathrm{~h}$ with administration of $50 \mu \mathrm{g}$ (five rats) or $100 \mu \mathrm{g}$ (four rats) unlabelled relaxin just before injection of ${ }^{125}$ I-labelled relaxin). Histograms show means \pm SEM. Significant difference from saline-infused rats at appropriate time after cessation of infusion: ${ }^{*} P<0.01$, ${ }^{* * *} P<0.001$.

for both uterus and cervix. At $3 \mathrm{~h}$ after termination of infusion of relaxin at $50 \mu \mathrm{g} \mathrm{kg}^{-1} \mathrm{~h}^{-1}$, uterine and cervical uptake of ${ }^{125} \mathrm{I}-$ labelled relaxin was significantly reduced compared with uteri and cervices from saline infused rats $(P<0.02, P<0.01$, respectively) and rats which received relaxin infusion at $20 \mu \mathrm{g}$ $\mathrm{kg}^{-1} \mathrm{~h}^{-1}(P<0.02, P<0.05$, respectively, Fig. 3a, b). By $12 \mathrm{~h}$ after termination of infusion, uterine and cervical uptake of ${ }^{125} \mathrm{I}$ labelled relaxin was similar in rats given an infusion of saline and in rats given an infusion of relaxin at $20 \mu \mathrm{gg}^{-1} \mathrm{~h}^{-1}$ or $50 \mu \mathrm{g} \mathrm{kg}^{-1} \mathrm{~h}^{-1}$. Administration of $50 \mu \mathrm{g}$ or $100 \mu \mathrm{g}$ unlabelled relaxin just before injection of ${ }^{125}$ I-labelled relaxin significantly reduced uterine and cervical ${ }^{125}$ I-labelled relaxin uptake in both saline-infused rats $(P<0.001)$ and in rats given an infusion of relaxin at $50 \mu \mathrm{g} \mathrm{kg}^{-1} \mathrm{~h}^{-1}(P<0.01)$. 
Table 3. Effect of glibenclamide $\left(20 \mathrm{mg} \mathrm{kg}^{-1}\right)$, phentolamine $\left(10 \mathrm{mg} \mathrm{kg}^{-1}\right)$ or vehicle $\left(0.2 \mathrm{~mol} \mathrm{NaOH} \mathrm{l}^{-1}\right.$ in $4 \%$ glucose or saline, respectively) on ratio of ${ }^{125}$ I-labelled relaxin content of tissue compared with ${ }^{125}$ I-labelled relaxin content of blood in reproductive and nonreproductive tissues from ovariectomized rats

\begin{tabular}{lcccc}
\hline Treatment & $\begin{array}{c}\text { Vehicle for } \\
\text { glibenclamide }\end{array}$ & Glibenclamide & $\begin{array}{c}\text { Vehicle for } \\
\text { phentolamine }\end{array}$ & Phentolamine \\
\hline Tissue & & & & \\
$\quad$ Uterus & $1.78 \pm 0.10$ & $1.67 \pm 0.09$ & $1.62 \pm 0.14^{\mathrm{a}}$ & $1.13 \pm 0.13^{\mathrm{a}}$ \\
Cervix & $1.88 \pm 0.17$ & $1.71 \pm 0.21$ & $1.72 \pm 0.23$ & $1.25 \pm 0.13$ \\
Bladder & $2.98 \pm 0.18$ & $2.55 \pm 0.32$ & $3.12 \pm 0.70^{\mathrm{b}}$ & $1.03 \pm 0.24^{\mathrm{b}}$ \\
Jejunum & $4.69 \pm 0.53$ & $2.45 \pm 0.75$ & $4.52 \pm 1.47^{\mathrm{c}}$ & $0.90 \pm 0.07^{\mathrm{c}}$ \\
Ileum & $2.24 \pm 0.85$ & $1.19 \pm 0.53$ & $0.65 \pm 0.03$ & $0.57 \pm 0.05$ \\
Diaphragm & $0.63 \pm 0.07$ & $0.65 \pm 0.04$ & $0.57 \pm 0.06$ & $0.42 \pm 0.03$ \\
Heart & $0.46 \pm 0.03$ & $0.46 \pm 0.03$ & $0.45 \pm 0.03$ & $0.41 \pm 0.01$ \\
Lung & $1.58 \pm 0.09$ & $1.78 \pm 0.15$ & $1.48 \pm 0.23$ & $1.16 \pm 0.13$ \\
& 5 & 5 & 5 & 5 \\
& 5 & 5 & & \\
\hline
\end{tabular}

Values are means \pm SEM. Values with the same superscripts are significantly different: $a, b, c, P<0.05$, (Student's $t$ test).

Nonreproductive tissues. ${ }^{125}$ I-labelled relaxin uptake in nonreproductive tissues was similar at $3 \mathrm{~h}$ and at $12 \mathrm{~h}$ after termination of infusion in both saline-infused and relaxininfused rats and was unaffected by administration of $50 \mu \mathrm{g}$ or $100 \mu \mathrm{g}$ unlabelled relaxin just before injection of ${ }^{125} \mathrm{I}$-labelled relaxin (data not shown).

\section{Experiment E: influence of glibenclamide and phentolamine on uptake of relaxin}

Uptake of ${ }^{125}$-labelled relaxin was similar in both glibenclamideinfused and vehicle-infused rats for reproductive and nonreproductive tissues (Table 3). Animals that received $10 \mathrm{mg}$ phentolamine $\mathrm{kg}^{-1}$ i.v. showed significantly reduced uterine uptake of ${ }^{125}$-labelled relaxin $(P<0.05)$ compared with salinetreated rats (Table 3). Cervical uptake of ${ }^{125} \mathrm{I}$-labelled relaxin was not significantly reduced by phentolamine treatment. ${ }^{125}$ I-labelled relaxin uptake was also significantly reduced by phentolamine treatment in bladder $(P<0.05)$ and jejunum $(P<0.05)$.

\section{Discussion}

In the study reported here specific uptake of ${ }^{125}$ I-labelled porcine relaxin over $60-120 \mathrm{~min}$ in anaesthetized rats was used as an indicator of both relaxin binding to specific receptors and subsequent internalization of the relaxin-receptor complex. Specific binding sites for relaxin have been demonstrated in reproductive tissues in vitro (Osheroff et al., 1990; Yang et al., 1992). It appears, however, that receptor density is naturally low in relaxin target tissues, rendering isolation and characterization of receptors for relaxin difficult (Yang et al., 1992). In the current experiments, highly purified porcine relaxin was radioiodinated and separated from unreacted and hydrolysed reagents by gel filtration. Labelled relaxin retained full biological activity: this was demonstrated in a separate experiment in which porcine relaxin was labelled with 'cold' Bolton-Hunter reagent and its ability to inhibit uterine contractions in vivo in conscious rats was confirmed. The study showed specific localization of ${ }^{125}$ I-labelled relaxin, as it could be displaced by unlabelled relaxin, in those tissues considered to be target tissues (uterus, cervix) but not in non-target tissues. It is, therefore, considered that sites of relaxin uptake and internalization were measured.

Treatment of rats with $0.4 \mu \mathrm{g}$ oestradiol benzoate $\mathrm{kg}^{-1}$ for 2 days resulted in a twofold increase in uterine sensitivity to relaxin as an inhibitor of spontaneous contractions (Downing and Hollingsworth, 1992a, b). In the study reported here, treatment with the same dose of oestradiol benzoate resulted in a significant increase (2.5-fold) in uterine uptake of ${ }^{125}$ I-labelled relaxin, although ${ }^{125}$ I-labelled relaxin uptake in cervix did not increase. Treatment with a high dose of $40 \mu \mathrm{g}$ oestradiol benzoate $\mathrm{kg}^{-1}$ further increased uterine uptake of ${ }^{125}$ I-labelled relaxin (3.5-fold over controls) and increased cervical uptake of ${ }^{125}$ I-labelled relaxin (fivefold over controls). In contrast, however, to the eightfold increase in uterine sensitivity to relaxin as an inhibitor of contractions produced by the lower dose of oestradiol benzoate plus progesterone treatment (Downing and Hollingsworth, 1992a), this steroid treatment did not increase uterine ${ }^{125}$ I-labelled relaxin uptake above that produced by $0.4 \mu \mathrm{g}$ oestradiol benzoate $\mathrm{kg}^{-1}$ treatment alone. Similarly, progesterone treatment did not increase uptake of ${ }^{125} \mathrm{I}$-labelled relaxin in the cervix. Progesterone may increase uterine sensitivity to relaxin by enhancement of coupling of relaxin receptors to second messenger systems within the myometrial cell, rather than by increasing relaxin receptor concentration. It is also possible that uptake of ${ }^{125}$ I-labelled relaxin by endometrium, which may not be influenced by oestrogen and 
progesterone treatment, could be obscuring changes in uptake of ${ }^{125}$-labelled relaxin occurring in the myometrium. Autoradiographic localization of uterine relaxin binding sites, however, indicates that these are predominantly in the myometrium, with little specific binding to endometrium in rats (Osheroff et al., 1990) and mice ( $($ ang et al., 1992). Thus, changes in uterine uptake of ${ }^{125}$ I-labelled relaxin may accurately reflect changes in myometrial relaxin binding. It has been reported that oestrogen pretreatment is necessary for the action of relaxin in promoting cervical softening and changes in connective tissue (Kroc et al., 1959; Cullen and Harkness, 1960; Downing and Sherwood, $1985 \mathrm{c}, 1986)$. Oestrogen may again increase coupling of relaxin receptors with second messenger systems in addition to raising concentrations of relaxin receptors in the cervix.

Prolonged i.v. infusion $(40 \mathrm{~h})$ of relaxin $\left(20 \mu \mathrm{g} \mathrm{kg}^{-1} \mathrm{~h}^{-1}\right)$ results in a significant (eightfold) reduction in uterine sensitivity to relaxin as an inhibitor of uterine contractions which is maintained for $24 \mathrm{~h}$ (Downing and Hollingsworth, 1992a). In contrast, no significant change in uptake of ${ }^{125}$ I-labelled relaxin was observed at either $3 \mathrm{~h}$ or $12 \mathrm{~h}$ after cessation of infusion in rats given a similar relaxin infusion compared with animals given a saline infusion. Prolonged infusion of relaxin at $50 \mu \mathrm{g} \mathrm{kg}^{-1} \mathrm{~h}^{-1}$ for $40 \mathrm{~h}$, which produces a 130 -fold reduction in uterine sensitivity to relaxin as an inhibitor of spontaneous contractions (Downing and Hollingsworth, 1992a), produced only a small reduction (1.5-fold) in uterine uptake of ${ }^{125}$ I-labelled relaxin at $3 \mathrm{~h}$ after termination of infusion. By $12 \mathrm{~h}$ after cessation of infusion, uterine uptake of ${ }^{125}$ I-labelled relaxin was similar to that observed in saline-infused rats. This finding suggests that development of tolerance may not be due primarily to internalization and loss of specific binding sites for relaxin, but may be due to uncoupling of receptors from second messenger systems in the myometrial cell. It is also possible that, in relaxin-tolerant tissues, relaxin is metabolized, and therefore lost, more rapidly.

Glibenclamide, a blocker of ATP-sensitive potassium channels, did not reduce ${ }^{125}$ I-labelled relaxin uptake in either uterus or cervix, suggesting an indirect mechanism for antagonism by glibenclamide of the inhibitory effect of relaxin on spontaneous uterine contractions (Downing and Hollingsworth, 1991) rather than glibenclamide acting as an antagonist at the relaxin receptor. Phentolamine, however, produced a significant reduction in ${ }^{125}$ I-labelled relaxin uptake in uterus, although cervical ${ }^{125} \mathrm{I}$ labelled relaxin uptake was unaffected by phentolamine treatment. A significant reduction in ${ }^{125} \mathrm{I}$-labelled relaxin uptake in bladder and jejunum suggests that phentolamine nonspecifically inhibits relaxin uptake. Phentolamine, by blockade of $\alpha$-adrenoceptors in blood vessels, may delay uptake of relaxin by the uterus owing to redistribution of blood flow.

This study demonstrates specific uptake of relaxin in the uterus and cervix of the rat in vivo which is increased by oestrogen pretreatment and is decreased in tissues tolerant to relaxin. Comparison of changes of relaxin uptake induced by oestrogen and tolerance with changes in sensitivity to the inhibitory action of relaxin on uterine contractions suggest that not only relaxin binding sites, but also signal-transduction mechanisms are modulated by oestrogen and development of tolerance.

The authors thank Action Research for financial support, J. Dawkins (Congerstone, Warwick, UK) for the supply of pregnant sow ovaries and Revertex Ltd (Harlow, Essex, UK) for the supply of latex.

\section{References}

Bencze WL and Schmid K (1957) Determination of tyrosine and tryptophan in proteins Analytical Chemistry 29 1193-1196

Bradshaw JMC, Downing SJ, Moffatt A, Hinton JC and Porter DG (1981) The demonstration of some of the physiological properties of rat relaxin Joumal of Reproduction and Fertility 63 145-153

Cheah S-H and Sherwood OD (1980) Target tissues for relaxin in the rat: tissue distribution of injected ${ }^{25}$ I-labeled relaxin and tissue changes in adenosine $3^{\prime}-5^{\prime}$-monophosphate levels after in vitro relaxin incubation Endocrinology $1061203-1209$

Cullen BM and Harkness RD (1960) The effect of hormones on the physical properties and collagen content of the rat's uterine cervix Journal of Physiology 152 419-436

Davis BJ (1964) Disc electrophoresis-II method and application to human serum proteins Annals of the New York Academy of Sciences $121404-427$

Downing SJ and Hollingsworth M (1991) Antagonism of relaxin by glibenclamide in the uterus of the rat in vivo British Journal of Pharmacology 104 71-76

Downing SJ and Hollingsworth M (1992a) Influence of ovarian steroids on myometrial sensitivity and tolerance to relaxin in the rat in vivo: lack of cross-tolerance among relaxin, salbutamol and cromakalim Journal of Endocrinology 135 17-28

Downing SJ and Hollingsworth M (1992b) Interaction between myometrial relaxants and oxytocin: a comparison between relaxin, cromakalim and salbutamol Journal of Endocrinology 135 29-36

Downing SJ and Sherwood OD (1985a) The physiological role of relaxin in the pregnant rat. I. The influence of relaxin on parturition Endocrinology 116 1200-1205

Downing SJ and Sherwood OD (1985b) The physiological role of relaxin in the pregnant rat. II. The influence of relaxin on uterine contractile activity Endocrinology 116 1206-1214

Downing SJ and Sherwood OD (1985c) The physiological role of relaxin in the pregnant rat. III. The influence of relaxin on cervical extensibility Endocrinology 116 1215-1220

Downing SJ and Sherwood OD (1986) The physiological role of relaxin in the pregnant rat. IV. The influence of relaxin on cervical collagen and glycosaminoglycans Endocrinology 118 471-479

Downing SJ, Mcllwrath A and Hollingsworth M (1992) Cyclic adenosine $3^{\prime} 5^{\prime}$-monophosphate and the relaxant action of relaxin in the rat uterus in vivo Joumal of Reproduction and Fertility 96 857-863

Hsu CJ, McCormack SM and Sanborn BM (1985) The effect of relaxin on cyclic adenosine $3^{\prime} 5^{\prime}$-monophosphate concentrations in rat myometrial cells in culture Endocrinology 116 2029-2035

Hughes SJ, Downing SJ and Hollingsworth M (1992) Relaxin, a potassium channel opener in the isolated rat uterus? British Journal of Pharmacology 106 $80 \mathrm{P}$

Kroc RL, Steinetz BG and Beach VL (1959) The effects of estrogens, progestagens and relaxin in pregnant and non-pregnant laboratory rodents Amnals of the New York Academy of Sciences 75 942-980

Lefkowitz RJ, Hausdorff WP and Caron MG (1990) Role of phosphorylation in desensitization of the $\beta$-adrenoceptor Trends in Pharmacological Sciences 11 190-194

Levitzki A (1986) Beta-adrenergic receptors and their mode of coupling to adenylate cyclase Physiological Review 66 818-854

Lowry OH, Rosebrough NJ, Farr AL and Randall RJ (1951) Protein measurement with the folin phenol reagent Joumal of Biological Chemistry 193 265-275

Mercado-Simmen RC, Bryant-Greenwood GD and Greenwood FC (1982) Relaxin receptor in the rat myometrium: regulation by estrogen and relaxin Endocrinology 110 220-226

Osheroff PL, Ling VT, Vandlen RL, Cronin MJ and Lofgren JA (1990) Preparation of biologically active ${ }^{32} \mathrm{P}$-labeled human relaxin: displaceable binding to rat uterus, cervix and brain Journal of Biological Chemistry $2659396-9401$

Osheroff PL, Cronin MJ and Lofgren JA (1992) Relaxin binding in the rat heart atrium Proceedings of the National Academy of Sciences, USA 89 2384-2388

Plant TD and Henquin JC (1990) Phentolamine and yohimbine inhibit ATP-sensitive $\mathrm{K}^{+}$channels in mouse pancreatic $\beta$-cells British joumal of Pharmacology 101 115-120

Porter DG, Downing SJ and Bradshaw JMC (1979) Relaxin inhibits spontaneous and prostaglandin-driven myometrial activity in anaesthetized rats Journal of Endocrinology 83 183-192 
Sanborn BM, Kuo HS, Weisbrodt NW and Sherwood OD (1980) The interaction of relaxin with the rat uterus. I. Effect on cyclic nucleotide levels and spontaneous contractile activity Endocrinology 106 1210-1215

Sherwood OD and OByrne EM (1974) Purification and characterization of porcine relaxin Archives of Biochemistry and Biophysics 160 185-196

Sherwood OD, Key RH, Tarbell MK and Downing SJ (1984) Dynamic changes of multiple forms of serum immunoactive relaxin during pregnancy in the rat Endocrinology 114 806-813
Tallarida RJ and Murray RB (1987) In Manual of Pharmacological Calculations with Computer Programs (2nd Edn) pp 31-35. Springer-Verlag, New York

Wiqvist N (1959) Desensitizing effect of exo- and endogenous relaxin on the immediate uterine response to relaxin Acta Endocrinologica 32 (Supplement 46) 3-14

Yang S, Rembiesa B, Bullesbach EE and Schwabe C (1992) Relaxin receptors in mice: demonstration of ligand binding in symphyseal tissues and uterine membrane fractions Endocrinology 130 179-185 